\title{
Self-Concept and Communication Adaptation of Newcomer Student in Unikom Bandung
}

\author{
Manap Solihat \\ Communication Science Departement \\ Universitas Komputer Indonesia \\ Bandung - Indonesia \\ manap.solihat@email.unikom.ac.id
}

\begin{abstract}
This study is aimed to depict communication adaptation and self-concept of newcomer student in learning environment at Unikom Bandung. The communication adaptation is explored through the adjustment of communication behavior that occured in every interaction between newcomer student, especially when they come and adjust themselves with the people, the environment, and new groups where they meet. This study uses qualitative approach with collecting data method that are carried out by interview (unstructured), non-participant observation and documentation study. Research result showed that: cultural similarities and geographical proximity are important factors in accelerating of adaptation process and there are relatively fewer obstacles compared to students who came from another island. All new students got the same experiences in facing the cultural shock, but the difference is the intensity of the time through the stage; the ones who tend to open themselves can overcome it more quickly than the ones who close themselves. The conclusion is that cultural and language diversity does not fully become a problem; the time, demographic, and weather factor create a problem for intercultural communication. Problems in intercultural communication can be reduced due to several factors, such as cultural closeness and self-disclosure. It makes them able to adapt well when communicating with friends in the environment.
\end{abstract}

Keywords: behavior adjustment, self-concept, extrovert, culture shock, diversity.

\section{INTRODUCTION}

Indonesia is a large country and there are various diversity, such as ethnicity, religion, race, and custom. In order to get an education or a better life, many people choose to go to other land, especially to Java. Bandung, as a major city of West Java, has many newcomer students. They must be able to survive with a new environment that is different from their origin. The differences may cause culture shock. Many research about this matter shows that the important things that should be done in an adaptation process are: the distance between students' new area of domicile to campus, social culture in students' place of origin to the students' new area of domicile, and the situation of environmental conditions (society) of students' place of origin to students' new domicile as well as individual specific views (attitudes and behaviors ) [1].

Culture shock that happens to every individual has symptoms and reactions in the form of mental and physical stress. Experiencing culture shock is normal for overseas students who begin new life in a new circumstances of different cultures. Four phases of culture shock are: optimistic phase (first phase), cultural issues (the second phase), the phase of recovery (third phase) and phase adjustment (last phase) [2].

A study shows that the culture shock could be handled through communication with Japanese and Indonesian expatriates. In addition, student's preparation, personality, and environment also influenced their adaptation process. The implication of this research is expected to be an overview for those who intend to continue their studies and educational institutions that offer various courses in Japan [3].

The communication system, verbal and non verbal, will differentiate each groups. There are certain needs like education or job that caused a person or a group move to another city. There is another research that try to find out how adaptation process of Papua students especially from area Sorong Selatan who came to Manado for education. The problems in the students' adaptation approach caused by some differences in culture, or pattern of communication, such as way of communication, life style, and habit. The response from Manado community to Papua students are not good. They think Papua students are jerk, fighter, and very stubborn people. This kind of judgement has impact to the process of adaptation. Papua students actually can be very nice, funny, and love to lugh, if they know each other better. The purpose of this research is to know how Papua students overcome these problems in the process of adaptation at District Malalayang, Manado [4].

Another research tried to describe the communication of the students in Faculty of Social Sciences and Humanities in adapting to the UIN Sunan Kalijaga environment. Based on the analysis of in-depth interviews, researchers found that the informants did venture proactive information retrieval in order to adapt to the environment at UIN Sunan Kalijaga. They are the individuals with their own personal identity and distinctive characteristics. When they communicate and interact socially, they do not lose their identity and uniqueness [5].

To deal with the different environment, they need do some adjustment or adaptation with new environment Students need to adapt of course, due to different living environment and campus environment from their origin. Not everyone can easily adapt. This disruption can lead to fatal things in academic and ability to get involve with their environment. According to Stavrianopolus (2008) on 
Spott's thesis (2011) states that the first year as a student is the most critical period. This period is a transition and adjustment to the social and academic guidance[6].

It is interesting to explore how these newcomer students instill their self-concept, self-awareness, self-esteem, and self-closure in new environment. Cultural different can also lead a shock to new culture also we can call culture shock. The process of adaptation in new environment will be influenced by self-concept from the newcomer student itself, this means personal factors are very important for the success of their adaptation. Because of that, the micro problem formulations are:

1. How do the newcomer students identify themselves in new environment?

2. How do the newcomer students pass through the culture shock phase ?

3. How do the newcomer student converge in a new environment?

\section{METHOD}

To discover the phenomenon of communication in multicultural culture, this research use qualitative research method with a symbolic interactionism approach. Subjective approaches to ethnic can be traced to definition from Cooley (1902) and Mead (1934) about 'self'. This approach criticizes positivistic approach because it limits the possibilities of human behavior that can be learned. Different from positivistic approach, which views individuals as passive and their change caused by the social powers outside from themselves, phenomenological approach views humans is far from passive [7]. These study use qualitative method, for describing the reality and social condition in the society. According to Nasution: qualitative approach is an approach based on the reality on the stage and what is experienced by the respondent.

The technique to collect data in this study are: (1) nonparticipant observation, (2) in-depth interview, and (3) document study. To solve the phenomena, this research use non participate observation technique. Technique of collecting data with open or in-depth interviews, which gives informants the freedom to give views freely (Koentjaraningrat, 1989: 30). This interview allows researchers to ask questions in depth. Therefore, to complete the data of this study, especially in an effort to get accurate data about this research, researcher made an interview with the informant. In this study, the interview that will be use is in-depth interview or non-structural interview. Non-structural interview close with informal conversation. This kind of interview is used because it is flexible; the arrangement of questions or words can be changed during the interview, adjusted to needs, and the condition of informant.

This study using qualitative approach which requires a detailed review of things there are specific to the object under study. Data analysis techniques are carried out by inductive analysis, it is a data collection and processing design to develop theory. To retract conclusions, the data collected is processed through a process of reduction, data presentation and verification.

\section{RESULT}

Newcomer Student Identifying Himself in New Environment

By knowing about students' perception about themselves, they can explore more about their strength and weakness of newcomer students in their readiness for new environment.

The informant we interviewed came from Bogor, then how he instill his self-concept to establish himself for study in Bandung and became newcomer student, was he prepared to face a different culture, and face many kind of situation.

In adolescence, of course you want try new things, wander is one of the desires that are very desirable. Apart from the wishes of parents, he felt that the quality of higher education in his hometown was not very good, especially the quality of private universities because the informants were not accepted at public universities in his hometown.

For self-preparedness in deal new environment, the informant had established their self-concept because the culture in Bogor and Bandung are close enough. From the language, the people friendliness, and the food. Besides that the friendship environment will be more diverse, here he must be more able to tolerate and appreciate the differences.

Basically our informants have prepared all the consequences that will be experienced because he knows self-concept is an important factor in interacting with his environment.

Another informant is came from Bangka Belitung City, in establishing their self-concept to study in Bandung, when they were in high school he took a study tour to Flower City. There were desire to study in Bandung, where the informant initially choose to continue his study to STIKOM but he refused because the building was too old and to quite. According to his friend's reference, finally he choose UNIKOM as a place to study for his bachelor's degree.

In making decision, he is influenced by the most important or significant other in which in the self-concept is learned through contact and experienced with others, learning to know themselves from the others.

Self-concept can be formed through self-views and positive experiences. Through these experiences, as experience has visited the city of Bandung can already imagine how it should face the cultural differences in Bandung, from a way of communicating that tend to use Sundanese, food as well he should be able to arrange because the food here is different from his home town, in addition to that with the cold Bandung air situation. All of this he has experienced during the study tour.

In addition to the experience of the environmental situation, self-confidence and positive thinking about different physical appearance because he comes from a family of Chinese descent and usually people who cannot 
tolerate will ridicule physical appearance or anything else. In talking to our informants sometimes it is still mixed with the accent from the region.

\section{Self-awareness}

In making decision it must be in full self-awareness from our informant, do not try to make decision in unstable emotion. With knowing about all the consequences that will come, our informant are aware with decision that was taken to continue their study in Bandung is their desires. This decision is based from the ego which consists of perception, memories, thought, and conscious feeling that work in conscious level of ego of self to find identity and existence of someone.

To emerge the self-awareness in making a decision, our informant convince themselves with asking themselves for their ability, what kind of limitation they need to improve. Informant looking themselves in different way, not only from one side but always learn about new culture which is different from his own culture.

In making decision to continue their study in Bandung, our informant has a goal, which the goal is to upgrade the education quality.

With high self-awareness, our informant is more ready to face an emergency situation or a sudden change, as experienced with our informant in early day of living in Bandung, he felt difficult to do anything by himself, he experienced anxiety such as difficult to sleep, filling upset because far from their parents, feeling alone because do not have a friend. But with positive thinking, he can through that stage.

Another option in making a decision to continue education in Bandung City informants are aware of the consequences that will be faced. Knowing your goals, habits, styles, strengths and weaknesses will make it easier to understand yourself.

The goal (motive) that encouraged them was to continue their education in Bandung, to get a bachelor's degree so that they could work in the company they wanted.

Self-awareness of habits, strengths and weaknesses is very important in order to be able to run easily in the face of new life that is far from parents, who are usually serviced and assisted. Our informant knows that he is used to doing everything himself taught at home, like making food. But one weakness of our informant is that he is used to being awake by his mother, which makes him often go to class late.

\section{Self-esteem}

At the beginning of arrival in Bandung, level of confidence of newcomer student is not too high, because they did not know the environment condition, what kind of friends will they got in Bandung.

When informants introducing themselves in new environment, they decide to not show the real character because there is a fear, not necessarily they will accept, and decide to observing first, and begin to more open.

Pessimistic thinking appears at the beginning of the lecture period, some are inferior because they come from a work environment that tends to adapt to an older person while being educated must adapt to the friendship environment that is more appropriate with him. The good responses faced in adapting to the lecture environment, they feel themselves appreciate by the lecture environment.

The level of confidence can be seen from how much the person feels positive about himself and that will make him better in action, mindset and behavior. With the realization of the consequences that will be faced in life away from parents, of course the students feel confident because he is the type of person who is easy to get along with and easily close to people.

Even in the introductory process, they easily get friends because they like to meet new people, so that they feel helped by having many friends. The environmental response was also quite good, they received it without being observed even though he came from outside the city of Bandung.

\section{Self-disclosure}

In social life in individual societies, people are often dogged by suspicion and lack of confidence so they do not dare to convey something to people. The informant can be open to the environment but depending on the person he knows, for example in a class atmosphere, he feels less mixed, less comfortable, narrow motion. They will be open to people who can make him comfortable.

It is not easy for newcomer students to tell everyone because they are afraid of the story being spread and tend to be careful in choosing people who can be trusted.

In the social life of the society, a person often feels suspicious and unsure to convey the various fluctuations and emotions that are in him to others, what is more about things he deems unnecessary for others to know. There are various types of people in this world, one of which is an extrovert which in the period of self-disclosure or selfintroduction he can easily get along with anyone, in telling stories and giving information he does not choose friends.

\section{Newcomer Student Go Through Culture Shock Phase}

Facing the cultural shock, newcomer students experienced the following phases (stages):

\section{1) Honeymoon Phase}

Newcomer students in the first time when they will continue their study in Bandung, they are very excited, enthusiastic about the new life they will live.

\section{2) Critical Phase}

Next, they realize if the reality is not same with their expectation. For example about a transportation, and a residence. They are confuse with it, because lack of information or friends to communicate and it is can make them frustrating.

3) Recovery Phase 
In this Phase, they begin to understand and know about their new culture. They make a plan in adjustment with new culture.

\section{4) Reconciliation Phase}

They are already satisfied and enjoy cultural differences, have been able to adjust to their new environment.

\section{DISCUSSION}

The results showed that the study about self-concept and communication adaptation of newcomer students at Unikom Bandung, :

1. Communication adaptation is someone ability in perceive the relation interpersonal in their social life and adjust the result of the perception into interaction social goals and social behavior defined communication adaptation as cognitive ability and behavioral to perceive sociointerpersonal relation and adapt with attitude and goals in interaction with others.

2. Openness of newcomer students is very necessary for the continuation of the adaptation process, so that newcomer students are expected to be more open to facilitate the adaptation process.

3. Cultural diversity among students can be used as a tool to get to know one student and another through a forum of activities available on campus.

4. In certain cases for students who have problems during the adaptation period with the campus environment can optimize the function of counseling institutions available in universities.

\section{V.CONCLUSIONS}

Based on the result of the study about selfconcept and communication adaptation of newcomer students at Unikom Bandung, we can conclude:

1. Cultural similarities and geographical proximity factors can be supporter for accelerating the process of adaptation and there are relatively few obstacles compared with student who came from another island. The different temperature it also become an obstacle in environment adaptation, because in Bandung the temperature is relative cooler.

2. In making decision it must be in full self-awareness from our informant, do not try to make decision in unstable emotion. With knowing about all the consequences that will come.

3. Newcomer students have difficulty in adaptation because they do not know how is the friendship environment will they get and they tend to choosing their friend to interact, while other students can easily adapt to new environment because he is type of open person and quick to get friend.

4. In self-disclosure or open up to new environment, newcomer students tend to choosing their friend because they are not easy to trust with other people, while the others are extroverted, easy to associate with anyone, while telling a story and giving information they do not choose the friend.

5. In facing the cultural shock phase, newcomer student got both of that phase experience, the different is the intensity of the time through the stage, who is tend to open themselves can through it more quickly than who is close themselves.

\section{REFERENCES}

1. Tukina, "Adaptation Process Of Students From Other Regions", HUMANIORA Vol.5 No.1 April 2014: 425-434)

2. Marshellena Devinta / Nur Hidayah dan Grendi Hendrastomo UNY, "Phenomenon of culture shock overseas students in yogyakarta", Jurnal Pendidikan Sosiologi 2015.

3. Faradita Prayusti "The Adaptation of Indonesian Students Facing Culture Shock in Fukuoka Japan: A Case Study of Indonesian Students in Kyushu University", 2017. London School Jakarta

4. Michel Talabessy, A. Walandouw, J. W. Londa, "Komunikasi Dalam Adaptasi Budaya e-journal "Acta Diurna” Volume IV. No.4. Tahun 2015)

5. Fajar Iqbal, "Communication and adaptation", Jurnal Komunikasi PROFETIK, Vol. 7, No. 2, Okober 2014

6. Martin, N. Judith, and Nakayama, K. T. "Intercultural communication in contexts". New York: Mc.Graw Hill.2000.

7. Mulyana, Deddy. "Qualitative research methods, a new paradigm of Communication and other Social Sciences". Bandung: Remaja Rosdakarya. 2001 